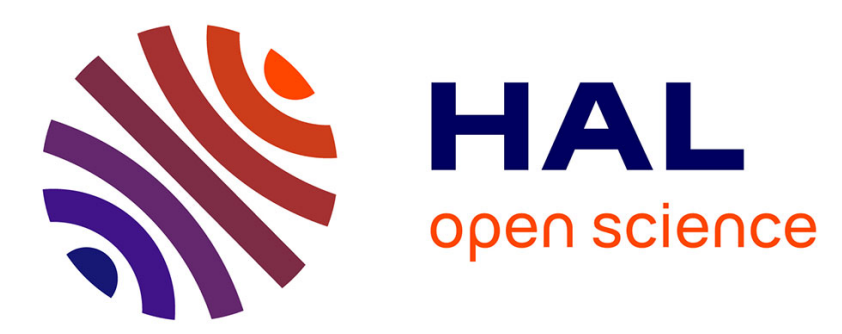

\title{
Automatic detection of the electron density from the WHISPER instrument onboard CLUSTER
}

\author{
Nicolas Gilet, Emmanuel de Leon, Klet Jegou, Luca Bucciantini, Xavier
} Vallières, Jean-Louis Rauch, Pierrette Décréau

\section{To cite this version:}

Nicolas Gilet, Emmanuel de Leon, Klet Jegou, Luca Bucciantini, Xavier Vallières, et al.. Automatic detection of the electron density from the WHISPER instrument onboard CLUSTER. 22nd EGU General Assembly, 0000, Online, Gabon. pp.2591-2599, 10.5194/egusphere-egu2020-18883 . insu03560746

\section{HAL Id: insu-03560746}

https://hal-insu.archives-ouvertes.fr/insu-03560746

Submitted on 8 Feb 2022

HAL is a multi-disciplinary open access archive for the deposit and dissemination of scientific research documents, whether they are published or not. The documents may come from teaching and research institutions in France or abroad, or from public or private research centers.
L'archive ouverte pluridisciplinaire HAL, est destinée au dépôt et à la diffusion de documents scientifiques de niveau recherche, publiés ou non, émanant des établissements d'enseignement et de recherche français ou étrangers, des laboratoires publics ou privés. 
EGU2020-18883

https://doi.org/10.5194/egusphere-egu2020-18883

EGU General Assembly 2020

(c) Author(s) 2022. This work is distributed under

the Creative Commons Attribution 4.0 License.

\section{Automatic detection of the electron density from the WHISPER instrument onboard CLUSTER}

Nicolas Gilet, Emmanuel De Leon, Klet Jegou, Luca Bucciantini, Xavier Vallières, Jean-Louis Rauch, and Pierrette Décréau

LPC2E-CNRS, ORLEANS CEDEX2, France (ngilet@cnrs-orleans.fr)

The Waves of HIgh frequency and Sounder for Probing Electron density by Relaxation (WHISPER) instrument, is part of the Wave Experiment Consortium (WEC) of the CLUSTER mission. The instrument consists basically of a receiver, a transmitter, and a wave spectrum analyzer. It delivers active (sounding) and natural electric field spectra. The characteristic signature of waves indicates the nature of the ambient plasma regime and, combined with the spacecraft position, reveals the different magnetospheric boundaries and regions. The electron density can be deduced from the characteristics of natural waves in natural mode and from the resonance triggered in the sounding mode. The electron density is a parameter of major scientific interest and is also commonly used for the calibration of the particles instruments.

Until recently, the electron density required a manual intervention consisting in visualizing input parameters from the experiments, such as the WHISPER active/passive spectrograms combined with the dataset from the other instruments onboard CLUSTER.

Work is being carried out to automatize the detection of the electron density using Machine Learning and Deep Learning methods.

To automate this process, knowledge of the region (plasma regime) is highly desirable. In order to try to determinate the different plasma regions, a Multi-Layer Perceptron has been implemented. This model consists of three neuronal network dense layers, with some additional dropout to prevent overfitting. For each detected region, a second Multi-Layer perceptron was implemented to determine the plasma frequency. This model has been trained with 100k spectra using the plasma frequency values manually found. The accuracy can reach until $98 \%$ in some plasma regions.

These models of the electron density automated determination are also currently applied on the dataset of the mutual impedance instrument (RPC-MIP) onboarded ROSETTA and will be useful for other space missions such as BepiColombo (especially for $\mathrm{PWI} / \mathrm{AM}^{2} \mathrm{P}$ experiment) or JUICE (RPWI/MIME experiment). 